Study the Advantage of Dermatoglyphic in Patients leukemia in Iraq Samar Abd AL-Wahab Abd Alla and Ibraheem Hadee Mohameed

\title{
Study the Advantage of Dermatoglyphic in Patients leukemia in Iraq
}

\author{
Samar Abd AL-Wahab Abd Alla ${ }^{1}$ and Ibraheem Hadee Mohameed ${ }^{2}$ \\ ${ }^{1,2}$ Department of Biology - College of Science - Diyala University \\ 1assaert.111@gmail.com \\ ²Dr.ibrahimhadi@sciences.u
}

Received: 17 June 2017

Accepted: 9 August 2017

\begin{abstract}
Finger print's patterns and patterns intensity were examined in a group of diagnosed cases of leukemia patients (100 males and females) who attended Baghdad Teaching Hospital; and the National Center for Hematology / Al-Mustansiryiah University. This group was compared with apparently healthy control group of 100 males and females -These finger patterns were analyzed qualitatively and quantitatively. The results showed increment in the number of arches, ulnar loops and decline in whorls, radial loops in both hands in males leukemia patients in comparison with healthy male and this increment reach a significant level $(\mathrm{P}<$ 0.0001; Chi-square test $=48.0819)$. In contrast in female leukemia patients there was a significant increment $(\mathrm{P}<0.0001$; Chi-square test= 33.928) in the number of arches, whorls and a decline in ulnar loops, radial loops in both hands, in comparison with healthy females. In quantitative analysis, TRC (Total Ridge counts) and ARC (Absolute Ridge Counts) have been collected and the TRC values were 107.849 in male patients and 111.968 for control males. The TRC values were 107.4 female patients and 100.616 for control females. In addition, the ARC values were 143.221 in male patients and 153.548 for control males while the were 153.044 in female patients and 129.067 for females in the control group.
\end{abstract}

Key wards: Dermatoglyphics, finger ridge count, Finger print's patterns. 


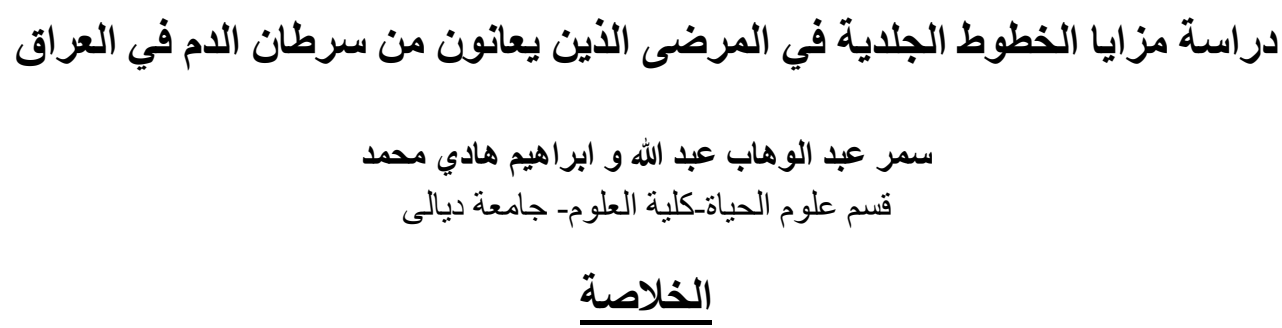

تم فحص أنماط طبعات الاصابع ومعامل شدة النمط في عينة مشخصة من المرضى المصابين بسرطان الام مكونة من 100 ذكور و اناث من المر اجعين لمستثفى بغداد التعليمي ومركز امر اض الدم /الجامعة المستصصرية وتمت مقارنتها بعينة قياسية مكونة من 100 ذكور و اناث (مجموعة السيطرة) ،هذه الطبعات للاصابع حللت نوعيا ( وصفيا) و كميا، اظهرت النتائج زيادة في اعداد الاقو اس ،العرويات الزندية وانخفاض في العرويات الكعبرية للذكور المرضى لكلا اليدين بالمقارنة بعينة الذكور الاصحاءوقد وصلت هذه الاخنلافات لمسنوى المعنوية عند استخدام اختبار مربع كاي = 48.0819 و احتمالية P P Pينما في الاناث المرضى ظهرت زيادة في الاقواس ،المستدير ات ونقصان في العرويات الزندية و الكعبرية في كلا اليدين بالمقارنة مع عينة لاناث اصحاء ووصلت هذه الاختلافات لمستوى المعنوية عند استخدام اختبار مربع كاي =33.928 نحت احتمالية 0.0001 > P. في التحليل الكمي جمعت منوسط العدد الكلي للخطوط TTRCو العدد المطلق ARC، وبلغت قيم TRCفي الذكور المرضى (107.849) وللأكور في مجموعة السيطرة (111.968) بينما بلغت قيمTRC في الاناث المرضى (107.4) وفي الاناث في مجمو عة السيطرة (100.616). اما قيم ARC في الذكور

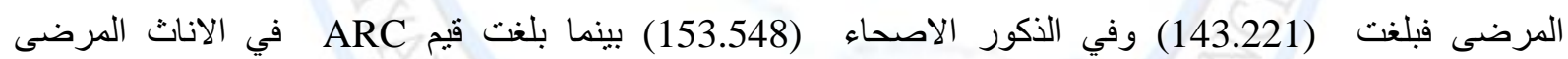
(153.044) وفي الاناث ا في مجمو عة السيطرة بلغت (129.067). الكلمات المفتاحية :الخطوط الجلدية ، تعداد تلال الاصابع ،انماط طبعات الاصابع.

\section{Introduction}

The dermatoglyphics care is concerned with the study of the patterns of skin ridges (dermal ridges) present on the fingers, descriptively and quantitatively, palm, toes and the soles of human and related species [1], as it is a single science in the field of biology, genetics and medicine proved to be important in giving some information about genetic defect [2]. The study of dermatoglyphics as a mean of medical diagnosis. Most cases of chromosomal disorders are associated with certain phenotype patterns of the dermatoglyphics. The irregular arrangement of the dermatoglyphics is not limited to cases of chromosomal aberration but 


\section{Study the Advantage of Dermatoglyphic in Patients leukemia in Iraq} Samar Abd AL-Wahab Abd Alla and Ibraheem Hadee Mohameed

also anomalies that are also caused by dysfunction of genes or genes with soft or genetic disorder in some genetic rules. In terms of the genetic composition of the skin ridges (dermal ridges), their characteristics are often regular and can distinguish them in the fourth month of the fetus's lifetime [3]. The characteristics remain constant during the lifetime of the individual and the composition of the skin ridges affected by different genetic factors and environmental distribution of these lines is not arbitrary when the transmission of its characteristics from the predecessor to the back. The dermatoglyphics in the field of medical genetics is of great importance as it was found to be associated with certain types of diseases, for example schizophrenia [4], bladder cancer [5], and Leukemia [6][7][8].

For a lack of studies on the relationship between leukemia and dermatoglyphics in Iraq, this study was proposed to investigate the possibility of using the dermatoglyphics as a tool for the diagnosis of the disease.

\section{Materials and Methods}

Dermatoglyphic prints of 100 diagnosed cases of leukemia patients who attended Baghdad Teaching Hospital, and the National Center for Hematology / Al-Mustansiryiah University, Baghadad, Iraq, during the period from April /2016 to March /2017. Finger prints were collected by using the ordinary ink method from 200 samples [100 diagnosed cases of leukemia (50 males and 50 females) and 100 healthy individuals (50 males and 50 females) as a control group]. These prints were printed on special sheets of paper contain sex and the prints of each finger in both hands. The finger prints were classified and analyzed as described previously $(9,10)$. The analysis was based on two conventions; the first was unilateral analysis - using one count per finger- and the second bilateral analysis - using two counts per finger. In the latter, an ulnar and a radial with one zero assigned in loops, and two zeros in arches. Sum of the first gives the total ridge counts (TRC) while the second represents absolute ridge counts (ARC). 
Study the Advantage of Dermatoglyphic in Patients leukemia in Iraq

Samar Abd AL-Wahab Abd Alla and Ibraheem Hadee Mohameed

\section{$\underline{\text { Results }}$}

\section{A: -Qualitative Analysis:}

Table (1) shows the pattern number and percentage of frequency of whorls, radial loops, ulnar loops and arches. It can be seen from this Table that the numbers of arches and ulnar loops were higher while the numbers of whorls and radial loops were lower in both hands in male leukemia patients (61 arches and 211 ulnar loops), in comparison with healthy males and the difference were significant ( $\mathrm{P}<0.0001$; Chi-square test $=48.0819$ ), while in female leukemia patients of the numbers of arches and whorls were higher, while the numbers of ulnar loops and radial loops in both hands were lower (72 arch and 181 whorl) than those in healthy females and the differences were significant $(\mathrm{P}<0.0001$; Chi-square test $=33.928)$.

Table 1: Comparison of tip ridge pattern of all fingers in both hands between control

\begin{tabular}{|c|c|c|c|c|c|c|c|c|}
\hline \multirow{3}{*}{ Samples } & \multirow{2}{*}{\multicolumn{2}{|c|}{ Whorls (W) }} & \multicolumn{4}{|c|}{ Loops } & \multirow{2}{*}{\multicolumn{2}{|c|}{ Arches (A) }} \\
\hline & & & \multicolumn{2}{|c|}{ Ulnar (Lu) } & \multicolumn{2}{|c|}{ Radial (LR) } & & \\
\hline & No & $\%$ & No & $\%$ & No & $\%$ & No & $\%$ \\
\hline Patients males $=50$ & 162 & 32.4 & 211 & 42.2 & 66 & 13.2 & 61 & 12.2 \\
\hline Standard males $=50$ & 194 & 38.8 & 144 & 28.8 & 132 & 26.4 & 30 & 6 \\
\hline Patients females $=50$ & 181 & 36.2 & 175 & 34.8 & 73 & 14.6 & 72 & 14.4 \\
\hline Standard females $=50$ & 144 & 28.8 & 177 & 35.4 & 139 & 27.8 & 40 & 8 \\
\hline Standard females $=50$ & 144 & 28.8 & 177 & 35.4 & 139 & 27.8 & 40 & 8 \\
\hline
\end{tabular}

and leukemia groups.

\section{B: Quantitative Analysis:}

\section{1-a: Unilateral Analysis for males:}

Table 2 shows the results of the unilateral analysis and it can be seen that finger 1 had the highest mean ridge counts in both hands of both male patients and control males while finger 5 had the lowest mean ridge counts in male patients. Finger 3 in right hand and finger 5 in left hand showed the lowest mean ridge counts in control males. 
Study the Advantage of Dermatoglyphic in Patients leukemia in Iraq Samar Abd AL-Wahab Abd Alla and Ibraheem Hadee Mohameed

Table 2: Unilateral analysis for 10 fingers in both hands of male patients and mles in control group

\begin{tabular}{|c|c|c|c|c|c|}
\hline \multirow{2}{*}{\multicolumn{2}{|c|}{ Finger }} & \multicolumn{2}{|c|}{ Male patients } & \multicolumn{2}{|c|}{ Control males } \\
\hline & & Mean & S D & Mean & S D \\
\hline \multirow{5}{*}{ 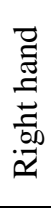 } & 1 & 11.568 & 3.281 & 13.939 & 3.788 \\
\hline & 2 & 10.810 & 3.717 & 11.239 & 3.984 \\
\hline & 3 & 10.930 & 3.801 & 9.978 & 3.671 \\
\hline & 4 & 10.844 & 3.133 & 11.674 & 4.551 \\
\hline & 5 & 10.660 & 3.607 & 10.333 & 3.191 \\
\hline \multirow{5}{*}{ 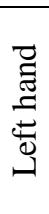 } & 1 & 11.244 & 3.809 & 12.571 & 3.769 \\
\hline & 2 & 10.075 & 3.547 & 10.848 & 4.179 \\
\hline & 3 & 10.561 & 3.775 & 10.409 & 3.744 \\
\hline & 4 & 11.357 & 3.875 & 10.956 & 3.529 \\
\hline & 5 & 9.800 & 3.811 & 10.021 & 3.546 \\
\hline \multicolumn{2}{|c|}{ Totals } & 107.849 & 36.356 & 111.968 & 37.952 \\
\hline
\end{tabular}

\section{1-b: Unilateral analysis for females:}

It can be seen from Table 3that finger 1 had the highest mean ridge counts in both hands of female patients and control females, while finger 5 had the lowest mean ridge counts in female patients. Finger 3 in right hand and finger 5 in left hand showed the lowest mean ridge counts in control females.

Table 3: Unilateral analysis for 10 fingers in both hands of females

\begin{tabular}{|c|c|c|c|c|c|}
\hline \multirow{2}{*}{\multicolumn{2}{|c|}{ Finger }} & \multicolumn{2}{|c|}{ Female patients } & \multicolumn{2}{|c|}{ Control females } \\
\hline & & Mean & S. D & Mean & S. D \\
\hline \multirow{5}{*}{ 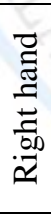 } & 1 & 12.864 & 4.578 & 13.755 & 4.206 \\
\hline & 2 & 10.767 & 4.297 & 8.909 & 3.620 \\
\hline & 3 & 10.366 & 3.579 & 8.391 & 3.435 \\
\hline & 4 & 11.911 & 4.363 & 10.061 & 3.971 \\
\hline & 5 & 9.346 & 2.560 & 9.200 & 3.329 \\
\hline \multirow{5}{*}{ 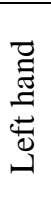 } & 1 & 11.182 & 4.363 & 12.314 & 4.022 \\
\hline & 2 & 10.256 & 3.830 & 9.971 & 4.138 \\
\hline & 3 & 10.244 & 4.375 & 9.000 & 3.811 \\
\hline & 4 & 10.488 & 4.930 & 10.152 & 3.590 \\
\hline & 5 & 9.976 & 4.063 & 8.863 & 3.583 \\
\hline \multicolumn{2}{|c|}{ Totals } & 107.4 & 40.938 & 100.616 & 37.705 \\
\hline
\end{tabular}




\section{Study the Advantage of Dermatoglyphic in Patients leukemia in Iraq} Samar Abd AL-Wahab Abd Alla and Ibraheem Hadee Mohameed

\section{2-a: Bilateral Analysis for males:}

According to Table 4, Finger 1 has the highest mean ridge counts in right hand while finger 4 has the highest mean ridge counts in left hand of female patients. Finger 1 has the highest mean ridge counts in control males for both hands, while finger 3 has the lowest mean ridge counts in right hand and finger 5 in left hand for both males patients and controls.

Table 4: Bilateral analysis for 10 fingers in both hands of males

\begin{tabular}{|c|c|c|c|c|c|}
\hline \multirow{2}{*}{\multicolumn{2}{|c|}{ Finger }} & \multicolumn{2}{|c|}{ Male patients } & \multicolumn{2}{|c|}{ Control males } \\
\hline & & \multirow{2}{*}{$\begin{array}{l}\text { Mean } \\
16.089\end{array}$} & \multirow{2}{*}{$\begin{array}{c}\text { S D } \\
6.934\end{array}$} & \multirow{2}{*}{$\begin{array}{c}\text { Mean } \\
19.816\end{array}$} & \multirow{2}{*}{$\begin{array}{c}\text { S D } \\
8.028\end{array}$} \\
\hline \multirow{5}{*}{ 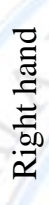 } & 1 & & & & \\
\hline & 2 & 14.500 & 7.188 & 15.311 & 8.218 \\
\hline & 3 & 13.581 & 7.465 & 12.689 & 7.991 \\
\hline & 4 & 15.867 & 7.473 & 17.326 & 9.269 \\
\hline & 5 & 12.894 & 7.385 & 12.646 & 5.789 \\
\hline \multirow{5}{*}{ 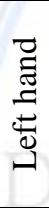 } & 1 & 15.578 & 8.220 & 18.592 & 8.558 \\
\hline & 2 & 13.325 & 7.454 & 15.500 & 8.500 \\
\hline & 3 & 13.585 & 7.868 & 12.955 & 7.424 \\
\hline & 4 & 16.535 & 7.753 & 16.239 & 7.798 \\
\hline & 5 & 11.267 & 6.081 & 12.474 & 6.530 \\
\hline \multicolumn{2}{|c|}{ Totals } & 143.221 & 73.821 & 153.548 & 78.105 \\
\hline
\end{tabular}

\section{2-b: Bilateral Analysis for females:}

Table 5 shows the mean of ridge counts and standard deviations for pattern types in both hands (female patients and control females). The results showed that finger 1 has the highest mean ridge counts in right hand while finger 4 has the highest mean ridge counts in left hand of female patients. In addition, finger 1 showed the highest mean ridge counts in control males for both hands, while finger 5 tends to have the lowest mean ridge counts in both hands in both female's patients and controls. 


\section{Study the Advantage of Dermatoglyphic in Patients leukemia in Iraq}

Samar Abd AL-Wahab Abd Alla and Ibraheem Hadee Mohameed

Table 5: Bilateral analysis for 10 fingers in both hands of females.

\begin{tabular}{|c|c|c|c|c|c|}
\hline \multirow{2}{*}{\multicolumn{2}{|c|}{ Finger }} & \multicolumn{2}{|c|}{ Female patients } & \multicolumn{2}{|c|}{ Control females } \\
\hline & & \multirow{2}{*}{$\begin{array}{c}\text { Mean } \\
18.295\end{array}$} & \multirow{2}{*}{$\begin{array}{c}\text { S D } \\
10.078\end{array}$} & \multirow{2}{*}{$\begin{array}{c}\text { Mean } \\
19.531\end{array}$} & \multirow{2}{*}{$\begin{array}{c}\text { S D } \\
9.030\end{array}$} \\
\hline \multirow{5}{*}{ 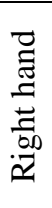 } & 1 & & & & \\
\hline & 2 & 14.674 & 8.524 & 11.523 & 6.997 \\
\hline & 3 & 13.150 & 7.008 & 8.978 & 4.924 \\
\hline & 4 & 18.311 & 10.262 & 12.612 & 7.659 \\
\hline & 5 & 15.349 & 8.208 & 10.220 & 5.441 \\
\hline \multirow{5}{*}{ 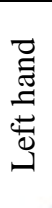 } & 1 & 15.659 & 9.035 & 18.824 & 8.145 \\
\hline & 2 & 14.395 & 8.318 & 13.941 & 8.503 \\
\hline & 3 & 13.951 & 9.471 & 10.308 & 6.606 \\
\hline & 4 & 15.927 & 9.781 & 13.918 & 7.994 \\
\hline & 5 & 13.333 & 8.233 & 9.980 & 5.809 \\
\hline \multicolumn{2}{|c|}{ Totals } & 153.044 & 88.918 & 129.067 & 71.108 \\
\hline
\end{tabular}

\section{Discussion}

According to Ministry of Health Iraqi Cancer Board 2009, leukemia is the third most common cancer in Iraq. The total number of cancer cases was 20,278 according to the Ministry of Health Iraqi Cancer Board 2011.The present study revealed that there was a significant increase $(\mathrm{P}<0.0001)$ in the number of arches, ulnar loops and a decline in whorls, radial loops in both hands in male leukemia patients in comparison with healthy males, while in female leukemia patients there was a significant increase $(\mathrm{P}<0.0001)$ in the number of arches and whorls and a decrease in ulnar loops, radial loops in both hands in comparison with healthy females. This finding was supported by AL-Jashammi [11] who found that there was an increase in the arch pattern and ulnar loop in both hand in male leukemia patients and an increase in whorl pattern in female leukemia patients in comparison with the control group. In the quantitative analysis, the results are similar to those of AL-Jashammi [11]. The results in female patients but not in male patients are similar to the findings of Dubowitz [6].

\section{Conclusion}

There is a possible genetic influence of the digital ridge patterns in leukemia patients. The use of dermatoglyphics is a unique and low-cost approach for identifying such individuals. This relatively noninvasive anatomical technique could reasonably be used for screening leukemia. Therefore, and according to these results, the present study suggests doing further studies including dermatoglyphics to distinguish the genetic parameters. 
Study the Advantage of Dermatoglyphic in Patients leukemia in Iraq

Samar Abd AL-Wahab Abd Alla and Ibraheem Hadee Mohameed

\section{$\underline{\text { References }}$}

1. Sharma ,M.K and Sharma , H. (2012). Dermatoglyphics: A diagnostic tool to predict diabetes. Journal of Clinical and Diagnostic Research, 6 (3): 327 - 332.

2. Katznelson ,M.B.; Bejerano, M.; Yakovenko, K.;Kobyliansk,Y. E.(1999). Relationship between genetic anomalies of different levels and deviations in dermatoglyphic traits. Part 4: Dermatoglyphic peculiarities of males and females with Down syndrome. Family study, Anthropol. An.57(3):pp:193-255.

3. Ganesh , K.SK. ; Avinash , S.S. ; Sreekantha ; Reimya .and Vinodchandran. (2014). Dermatoglyphics in primary hypertensive patients. International Journal of Pharma and Bio Sciences, 5 (1): 53-58.

4. Solar ,J.;Ferentinos ,P.;Prats , C.;Miret,C.;Giralt ,M.; Peralta , V.; Fananas .and Fatjovalas , M . (2017)Familial aggregation of schizotypy in schizophrenia - spectrum disorder and its relation to clinical and neurodevelopmental characteristics. Journal of Psychiatric Research, 84: 214-220.

5. Gali, K.H. (1997). Study of chromosome and dermatoglyphics of palm in patients with bladder cancer. Master Thesis, Faculty of Education Ibn Al-Haitham / Baghdad University, Baghdad, Iraq.

6. Dubowitz, U. (1969). Dermatoglyphics of leukemia in children. The lancet, 14:1219.

7. Verbov,J.L. (19970). Dermatoglyphics in leukemia. Journal of Medical Genetics, 7: 125131.

8. Wertelecki,W.;Plato,C.C.and Jr Faumeni ,J.F. (1969). Dermatoglyphics in leukemia. The lancet, 2: 806-807.

9. Cummins , H. (1964). Dermatoglyphics: Abrief review ,in: Montagina,W. and Lobits,W.C.(Eds).The epidermis . Academic press,U.K.:375-386.

10. Holt, S. B.( 1968).The genetic of dermal ridges, Spring field, C. C. Thomas, I llonois, ,PP: 105-120.

11. AL-Jashammi, Z.A.K. (2000). A study of chromosomal karyotyping and Dermatoglyphics of patients with Chronic myeloid leukemia in Iraq, college of Education Ibn Al-Haitham / Baghdad University. 